\title{
REGULATING CONSUMER BANKRUPTCY: A THEORETICAL INQUIRY
}

\author{
BARRY ADLER, BEN POLAK, and ALAN SCHWARTZ*
}

\begin{abstract}
This paper uses a principal/agent framework to analyze consumer bankruptcy. The bankruptcy discharge partly insures risk-averse borrowers against bad income realizations but also reduces the borrower's incentive to avoid insolvency. Among our results are the following: (a) high bankruptcy exemptions increase bankruptcy insurance but at the cost of reducing the borrower's incentives to stay solvent; (b) reaffirmations - renegotiations - have ambiguous efficiency effects in general, but the right to renegotiate is especially valuable for relatively poor persons; (c) giving consumers the ex post choice regarding which bankruptcy chapter to use also provides more insurance but, by making bankruptcy softer on debtors, has poor incentive effects; and $(d)$ serious consideration should be given to expanding the scope of consumers' ability to contract about bankruptcy because trade-offs between risk and incentives are context sensitive and, thus, are poorly made in statutes of general application.
\end{abstract}

\section{INTRODUCTION}

\section{A. The Subject}

A

VERY large fraction of bankruptcy filings each year are by consumers, the number of consumer filings per year is steadily increasing, and consumer bankruptcy is a hot, and controversial, political issue. Consumer bankruptcy, however, has received little theoretical analysis despite its practical and political significance. The four dissenters (out of nine members) to the recent Report of the National Bankruptcy Review Commission (NBRC) thus remarked on "the need for a coherent theory of consumer bankruptcy,"' and an empirical study published recently stated: "But de-

* Adler is at School of Law, New York University; Polak is at Department of Economics, Yale University; Schwartz is at School of Law, Yale University. This paper was improved by comments at the conference Political Economy of Contractual Obligations: The Case of Bankruptcy Law, Lake Arrowhead, California, April 1999; by workshops at the University of Florida College of Business and the Case Western Law School; and by suggestions from Ian Ayres, Andrew Guzman, Eric Posner, Howard Rosenthal, and George Triantis.

${ }^{1}$ The NBRC was appointed by Congress to recommend to it reforms of the Bankruptcy Code. A number of recent reform bills have been introduced in Congress in the last 2

[Journal of Legal Studies, vol. XXIX (June 2000)]

(c) 2000 by The University of Chicago. All rights reserved. 0047-2530/2000/2902-0001\$01.50 
spite the importance of personal bankruptcy, the subject has been almost completely neglected by economists." 2 This paper is an early effort to uncover some of the theoretical issues.

To better understand the gap we attempt to fill, realize that most of the scholarship on business bankruptcy has taken an ex post focus, concentrating on what should be done after a firm has become insolvent. In this context, there is an uncontroversial goal and a consensus on the need for regulation to achieve it. The goal is to continue the insolvent firm as an economic entity if its going concern value exceeds its liquidation value. When this inequality is unsatisfied, the firm should be liquidated piecemeal. Regulation may be necessary because the goal of an individual creditor is to maximize its insolvency state payoff. Sometimes this is best done by promptly suing a debt to judgment and seizing particular assets of the firm. When more than one creditor acts on this incentive, the likely equilibrium is for all insolvent firms to be liquidated. Therefore, a bankruptcy system that stays collection and then weighs going concern and liquidation values is necessary to achieve ex post efficiency.

There is no similar ex post efficiency paradigm for consumer bankruptcy. The insolvent consumer cannot be liquidated, but rather will continue on, doing what he had done. Also, if there is a collective action problem, it must take a different form than it takes for business bankruptcy. To see why, suppose there were no bankruptcy procedure and one creditor rushed to judgment, seizing most of the insolvent consumer's assets. This would injure the other creditors, but the injury is only a wealth transfer. As just said, the consumer will go on as before, whether one creditor takes the lion's share or the creditors share ratably. What then is the ex post efficiency goal that a consumer bankruptcy system should pursue? What impediments to the realization of that goal must the system eliminate? These questions seldom are asked.

Business bankruptcy scholarship has only recently devoted serious attention to ex ante efficiency. From an ex ante point of view, a bankruptcy system can be regarded as a term in a lending agreement. The issues are what optimal "bankruptcy terms" would look like and whether the private parties could agree on them. ${ }^{3}$ Scholars also have asked whether firms do, or

years. See 1 Report of the National Bankruptcy Review Commission (1997). The Report cites much of the legal literature relating to consumer bankruptcy.

${ }^{2}$ Reint Gropp, John Karl Scholz, \& Michelle J. White, Personal Bankruptcy and Credit Supply and Demand, 112 Q. J. Econ. 217 (1997).

3 See Alan Schwartz, A Contract Theory Approach to Business Bankruptcy, 107 Yale L. J. 1807 (1998); Alan Schwartz, Contracting about Bankruptcy, 13 J. L. Econ. \& Org. 127 (1997). 
free from legal constraint might, choose capital structures or corporate charters that take bankruptcy into account. ${ }^{4}$ In contrast, apart from occasional suggestions that bankruptcy partially insures consumers against bad income realizations, consumer bankruptcy scholarship has neglected ex ante efficiency altogether. As it happens, consumer bankruptcy is best justified as partial wage insurance, ${ }^{5}$ but then the issue is whether current bankruptcy procedures resemble an optimal insurance contract against personal insolvency. This issue has been almost entirely neglected. We therefore write on a relatively clean slate and will raise more questions in this paper than we answer.

\section{B. The Consumer Bankruptcy System}

A consumer borrower has a nonwaivable right to bankruptcy relief and a choice as to the form that relief can take. When the debtor files for bankruptcy under Chapter 7 of the Bankruptcy Code, he must give up his nonexempt assets ${ }^{6}$ to his creditors in return for a discharge of his debts. After a Chapter 7 discharge, the borrower emerges from bankruptcy with all of his exempt assets and all of his human capital. Alternatively, a debtor can file for bankruptcy under Chapter 13. This debtor must propose a plan, acceptable to the bankruptcy court, under which he can keep his exempt and nonexempt assets, but he must pay all of his "disposable income" to his creditors in installments. The present value of these installments must at least equal the value of the debtor's nonexempt assets. A Chapter 13 repayment plan is supposed to last for 3-5 years. As this sketch suggests, a debtor will

${ }^{4}$ See Barry E. Adler, A Theory of Corporate Insolvency, 72 N.Y.U. L. Rev. 343 (1997); Barry E. Adler, Financial and Political Theories of American Corporate Bankruptcy, 45 Stanford L. Rev. 311 (1993); Robert A. Haugen \& Lemma W. Senbet, Bankruptcy and Agency Costs: Their Significance to the Theory of Optimal Capital Structure, 23 J. Fin. \& Quan. Analysis 27 (1988). See also Robert K. Rasmussen, Debtor's Choice: A Menu Approach to Corporate Bankruptcy, 71 Texas L. Rev. 51 (1992).

5 Wage insurance apparently is not sold in standard insurance markets. Current analyses now show that many individuals do not hold sufficient financial assets to permit complete consumption smoothing. See, for example, George M. Constantinides \& Darrell Duffie, Asset Pricing with Heterogenous Consumers, 104 J. Pol. Econ. 219 (1996); Alon Brav, George M. Constantinides, \& Christopher C. Geczy, Asset Pricing with Heterogenous Consumers and Limited Participation: Empirical Evidence (unpublished manuscript, Univ. Chicago, Grad. Sch. Bus. 1999).

${ }^{6}$ Bankruptcy law partitions a debtor's assets into two classes, those that creditors cannot reach (exempt assets) and those that creditors can reach (nonexempt assets). It also is common to put a monetary limit on exemptions. For example, the debtor's home usually is exempt, but a state may restrict the exemption to equity worth no more than $\$ 20,000$. The Bankruptcy Code itself contains a set of exemptions, but it also permits the states to choose their own exemption categories and levels. A majority of states have done so. 
file under Chapter 13 when he values his nonexempt assets more than the fraction of his future earnings that the court-approved plan will require him to give up. ${ }^{7}$

Several reforms of the consumer bankruptcy system have been introduced in Congress in recent years. Some reformers would like to increase the federal exemption level and make it binding on the states. This would permit most consumers to emerge from bankruptcy with more property than they can today. After bankruptcy, some consumers "reaffirm," and thereby reinstate, certain debts in order to retain property a creditor could otherwise seize or to increase the chance of obtaining more credit from a particular creditor. The NBRC believes that consumers often reaffirm debts unwisely and that the relatively poor are particularly prone to exploitation in renegotiations. Similar views support the current extensive regulation of reaffirmations (for example, a renegotiation bargain must be approved by the bankruptcy court). The NBRC recently recommended reforms that would eliminate reaffirmations altogether. ${ }^{8}$ Other reformers sometimes argue that consumers should be permitted to waive their right to, or agree to conditions on, a bankruptcy discharge (in order to obtain a lower interest rate). In another vein, a number of commentators now advocate "needs-based"' bankruptcy. Under such a system, an insolvent debtor whose future income is expected to be above a statutorily set level would be required to use Chapter 13. The object here, often cast in moral terms, is to prevent a consumer with relatively few nonexempt assets and high expected earnings from painlessly discharging a large amount of debt. As an illustration, consider a debtor who has $\$ 50,000$ in nonexempt assets, has debts of $\$ 350,000$, and will earn $\$ 100,000$ per year after bankruptcy. This debtor can file under Chapter 7 , sell his debt to his creditors for one-seventh of its face value, and retain his future income. It is arguably more equitable to force the debtor to use Chapter 13, which would require him to share much of his future income with creditors. The desirability of these currently proposed reforms and others could be better assessed were there a more solidly grounded theoretical understanding of consumer bankruptcy.

\footnotetext{
7 A recent empirical analysis stated, "The data clearly suggest that .. . Chapter 13 debtors are protecting asset holdings by their choice of chapter." Ian Domowitz \& Robert L. Sartain, Incentives and Bankruptcy Chapter Choice: Evidence from the Reform Act of 1978, 28 J. Legal Stud. 461, 472 (1999).

${ }^{8}$ The NBRC recommended that reaffirmations of unsecured debt be prohibited and that reaffirmations of secured debt be limited to the wholesale value of the collateral. Since the secured creditor could realize the wholesale value by repossessing, it probably would reject a deal to be paid no more than that value in installments.
} 


\section{Tentative Results and Open Questions}

The Bankruptcy Code is a mandatory term in the lending agreement. When credit markets are competitive, as we suppose, the borrower side gets the entire ex ante surplus that credit makes possible. This implies that the private and socially efficient outcomes are the same: a borrower prefers the contract that maximizes his expected surplus, and this contract also will maximize expected social surplus (if there are no externalities). Turning to the borrower's preferences, many scholars and reformers believe that insolvency is exogenous: the consumer borrower becomes insolvent through no fault of his own, in consequence of job loss, illness, or the like. ${ }^{9}$ On this assumption, we first show the standard result that when insurance is actuarially fair and consumers are risk averse, the efficient contract insures the borrower fully. A Chapter 7 discharge is not full insurance: the debtor is "paid" the value of his unpaid debts but not the full loss he may incur from a bad income realization. Were the Bankruptcy Code to become a default, borrowers thus would reject contracts that waived discharge unless they received an appropriate risk premium. Needs-based bankruptcy also would be ex ante inefficient in a world of exogenous bankruptcy because it would require wealthier borrowers to pay their disposable future income to creditors for some years and so would provide little insurance.

It is more realistic to suppose that bankruptcy is partly endogenous. A borrower, for example, commonly has some control over whether he works and how much he earns. If moral hazard exists, then consumer bankruptcy policy issues raise the standard trade-off between risk and incentives. Because wage insurance in the United States is less than full, a risk-averse borrower prefers as complete a discharge as the law can grant; but because the extent of moral hazard varies inversely with the extent of insurance, a surplus-maximizing borrower may prefer to realize the efficiency gain from contracting for a limited discharge. As a consequence, both Chapter 7's full discharge and Chapter 13's attempt to lien all of the borrower's disposable income reflect "corner solutions" that seldom are optimal.

Taking moral hazard into account also permits us to shed some light on other reform proposals. Raising the exemption level exacerbates moral hazard and thus worsens ex ante efficiency. Indeed, if a consumer has too few assets to give up to creditors, he may be unable to borrow. This result may explain recent empirical data that poor consumers have relatively more difficulty getting credit in states with higher exemptions. ${ }^{10}$ Consumer mort-

${ }^{9}$ See Teresa A. Sullivan, Elizabeth Warren, \& Jay L. Westbrook, As We Forgive Our Debtors: Bankruptcy and Consumer Credit in America (1989).

${ }^{10}$ See Gropp, Scholz, \& White, supra note 2 . These authors informally attribute credit denials to low-income consumers to asymmetric information. 
gages could partly mitigate this inefficiency because they convert exempt into nonexempt assets and so increase the creditors' insolvency state payoff. Consequently, efforts to restrict the ability of consumers to give security and the Code's prohibition of exemption waivers are questionable. ${ }^{11}$

Reaffirmations have an ambiguous efficiency effect. When an insolvent borrower can trade future income for current assets, the creditor's expected insolvency state payoff increases, and this in a competitive credit market will reduce the interest rate. This reduction in turn improves the borrower's incentive to avoid bankruptcy because the lower the interest rate, the larger is the borrower's share of the solvency state marginal return from effort, and the more effort he will exert to maximize that return. ${ }^{12}$ If poor borrowers have relatively little bargaining power, then reaffirmations will help the poor the most. ${ }^{13}$ Such borrowers may have to share much ex post surplus with their creditors, and this will have two desirable efficiency effects. The consequent reduction in the interest rate will cause the borrower to work harder to avoid insolvency for the reasons given; and because bankruptcy remains tough on the borrower, renegotiation does not much reduce his incentive to avoid it. Renegotiation for poor borrowers thus may often be efficient and as a consequence will also be in the poor consumer's ex ante best interests (recall that borrowers capture the surplus from efficient lending agreements). This implies that reaffirmations should be encouraged. $^{14}$

${ }^{11}$ Section 522(e) of the Bankruptcy Code makes exemption waivers unenforceable.

12 Yeon-Koo Che \& Alan Schwartz, Section 365, Mandatory Bankruptcy Rules and Inefficient Continuance, 15 J. L. Econ. \& Org. 441 (1999), analyzes a similar trade-off in the business context. See also Barry E. Adler, Bankruptcy and Risk Allocation, 77 Cornell L. Rev. 439, 475-76 (1992).

${ }^{13}$ The term "poor" in text is less accurate than such descriptives as the "lower middle class" or the "working poor": over 87 percent of Chapter 7 debtors and over 99 percent of Chapter 13 debtors are employed. See Domowitz \& Sartain, supra note 7. Our points regarding reaffirmations also should not be overstated because a tough bankruptcy procedure may provide less insurance than some consumers would want.

${ }^{14}$ The NBRC was concerned that reaffirmations were inconsistent with the goal of treating creditors equally. A creditor with low monitoring costs has the ability to exact a reaffirmation, while other creditors will have their claims entirely discharged. This argument is unpersuasive because the equality goal is misplaced in this context. An equality argument presupposes a metric: firms or persons may be said to be unequal along a particular dimension, such as wealth. The NBRC did not set out a metric. To see why this failure is fatal, consider the concern that some creditors are better placed or are better at collecting debts than others. All creditors, however, had a chance to improve their collection opportunities and abilities. Thus, there would be inequality of opportunity only if firms who are allowed to profit from their commercial talents when extending credit initially should not be allowed to profit from their commercial talents when collecting debts. The NBRC does not explain why the equality goal should be so selectively pursued. The NBRC perhaps was striving for equality of result among creditors, but this would have been a mistake because there already is equality of result. The price for credit will reflect the creditor's insolvency state payoff. Hence, creditors 
Finally, permitting debtors ex post to choose which bankruptcy chapter to use seems questionable. Because parties can renegotiate in Chapter 7, Chapter 13 cannot increase ex post surplus. Debtors, we show, choose the chapter that minimizes the creditors' insolvency state payoff. This worsens ex ante efficiency because interest rates rise and bankruptcy is softer on borrowers. Permitting debtors to choose between Chapters 7 and 13 thus does not enhance ex post efficiency and reduces ex ante efficiency. On the other hand, very risk averse borrowers may prefer ex ante to have the choice because it increases the amount of insurance that the bankruptcy system provides. Given heterogeneity among borrowers, this analysis suggests permitting borrowers to waive their right in the lending agreement to choose between chapters.

This last policy suggestion leads to a basic point of this article. Optimal trade-offs between risk and incentives are context dependent; they depend on the degree of a party's risk aversion and her ability to affect the probability and magnitude of a bad outcome. Society commonly permits persons to make the risk/incentive trade-off for themselves. As an example, the consumer can choose the size of the deductible in most insurance policies. This suggests that borrowers should have a similar freedom to choose the extent of "bankruptcy insurance" they want to purchase. Bankruptcy contracting, however, raises issues that are present in lesser degree in other contracting contexts: that is, a bankruptcy contract may involve many parties, some of whose interests may conflict; the contracts are intertemporal in scope; and they may cause externalities. Because this article does not analyze these contracting difficulties, its principal goal is to exhibit the efficiency gains that could follow from a relaxation of the current prohibitions on consumer bankruptcy contracting, and thus to make central the questions whether such contracting would be normatively desirable, all things considered, and technically feasible.

\section{The Scope and Limits of the Analysis}

Recent analyses of consumer bankruptcy have considered cognitive error-the borrower irrationally incurs too much debt-and political economy. Regarding the former, this paper restricts itself to the rational actor paradigm. At this stage, it seems best to see what an efficient bankruptcy system would look like on the assumption that all of the actors in it are capable of maximizing expected utility. Later analyses should ask which

who are inefficient debt collectors will charge a higher price for credit than the good collectors. But in a competitive credit market, all creditors earn zero profits: the pure profit from efficient collection is competed away. Therefore, there now is equality of result. 
otherwise optimal rules would have to be modified if consumers make systematic cognitive errors.

We do not systematically explore the political causes of the current system, again because it seems best to begin with substance. Our analysis is related to politics, however. Political economy analyses have a normative component. For example, a regulator is said to be captured if political pressures caused her not to do what she should do. Thus, it is helpful to be able to say what regulators should do about consumer bankruptcy. We go on in the conclusion, however, to suggest that much of current law exists in consequence of pressure from the bankruptcy bar and judges, who are the system's greatest concentrated beneficiary group.

Section II analyzes the consumer bankruptcy system on the assumption that bankruptcy is exogenous. Section III relaxes this assumption to consider moral hazard. Section IV is a conclusion that summarizes the normative implications of the analysis and suggests directions for future research.

\section{BANKRUPtCY Without MORAL HaZARD}

\section{A. A Simple Model}

A risk-averse consumer borrows the sum $D$ in period 0 , promising to repay $R>D$ in period 1 . The loan enables the borrower to get some nonpecuniary or illiquid benefit worth $B$ to him. The borrower's period 1 income is subject to a random shock. With probability $\pi$ he earns $y>R$, pays the debt, and retains disposable income; with probability $(1-\pi)$ he earns zero and is insolvent that period. The present value of his future income in periods after period 1 is $Y$, which, for simplicity, is assumed to be determinate. ${ }^{15}$ For now, suppose that the consumer has no assets and cannot affect the probability of period 1 insolvency.

In the absence of a bankruptcy law, a borrower who has a good realization earns $y$, repays $R$, and then has wealth of $B+y-R+Y$. A borrower who has a bad realization repays nothing in period 1 but - since he cannot declare bankruptcy - must repay the debt out of future earnings. His wealth in this circumstance is $B+Y-R$.

\section{B. Insurance}

A bankruptcy discharge provides the borrower with partial wage insurance. In this model, a borrower's expected wealth at the beginning of period 1 is $B+Y-R+\pi y$. A risk-averse borrower prefers to have this expected

\footnotetext{
${ }^{15}$ We assume for convenience that the solvent debtor spends the remainder of his period 1 income after paying the debt.
} 
wealth in both possible future states with certainty. Failing that, he would accept some reduction in his wealth in the good state in return for an increase in his wealth in the bad state. Chapter 7 discharges the debtor when he is insolvent. Thus, his insolvency state wealth is simply $Y+B$, the present value of his future income as if the loan had never been made plus the benefit the borrower received from the loan. Since the borrower would pay nothing to creditors in the bad state, he must agree to pay them more in the good state. In a competitive credit market, in which the creditors earn zero profits, the sum the borrower agrees to repay, $R$, must equal the expected value of the loan, $D: D=\pi R+(1-\pi) 0$, so that $R=D / \pi$. The borrower's good-state wealth thus becomes $B+Y+y-D / \pi$. Since we assume that $y>R=D / \pi$, the borrower has greater wealth in the good state than in the bad state, in which his wealth is only $B+Y$; hence, the bankruptcy discharge does not fully insure the borrower against a shock to his wage income.

This analysis has two normative implications. First, in this world of exogenous bankruptcy, consumer borrowers would not waive their right to a bankruptcy discharge in return for a lower interest rate if the interest rate difference only equaled the expected value of the creditor's loss from default. A borrower would forgo "discharge insurance" only if he also was paid a risk premium. Lenders would not pay risk premiums because the interest rate is set by competition to equal the expected value of the sum the borrower receives. Thus, a lender who also offered a risk premium would incur losses. The issue whether consumers should be free to waive the right to discharge therefore seems unimportant on the assumptions made so far. Second, in this model, in which the borrower has no assets, needs-based bankruptcy would plainly be suboptimal. Under that system, a debtor with a relatively high future income would be required to repay as much of the debt $R$ as his circumstances permit. The borrower thus would have less insurance than he would be willing to purchase.

\section{MORAL HAZARD}

\section{A. The Basic Analysis}

In analyzing moral hazard, we add three assumptions to the model in Section IIA:

Assumption A1. Borrowers now are risk neutral.

Assumption A2. The cause of bankruptcy is partly endogenous: that is, borrowers can affect the probability of bankruptcy through their own actions.

Assumption A3. Creditors cannot observe either a borrower's actions 
or their effect on the bankruptcy probability; that is, effort is noncontractible.

Assumption A1 is made for convenience: we return to the more realistic assumption that borrowers are risk averse below. Regarding assumption A2, while medical debt is an important cause of bankruptcy, and is largely beyond a borrower's control, increases in unsecured debt, especially credit card debt, relative to income substantially increase the probability of bankruptcy. ${ }^{16}$ Incurring debt, managing one's financial affairs, and working hard at a job are substantially within a borrower's control. Formally, we capture the existence of moral hazard by making the support of the outcome distribution-the borrower earns either zero or $y$ in period 1 -be independent of the borrower's effort, but we allow effort to alter the distribution on the fixed support. Assumption A3 is made because it seems true: were creditors able to monitor borrowers perfectly, very different credit contracts would be observed.

Turning to the analysis, $\pi$ remains the probability of solvency but now depends on the buyer's efforts. Let $\psi(\pi)$ be the disutility cost of effort to a borrower, and suppose that $\psi(0)=0 ; \psi^{\prime}>0 ; \psi^{\prime \prime}$ and $\psi^{\prime \prime \prime}>0$; and $\psi(1)$ $=\infty$. In brief, the borrower faces increasing marginal costs to reduce the probability of insolvency, and he cannot reduce this probability to zero no matter how hard he works. Recall from Section IIA that in a competitive credit market, the borrower promises to repay $R=D / \pi$. This is the creditors' zero profit participation constraint. The variables $R$ and $\pi$ are endogenous: $R$ is part of the loan contract, and the borrower chooses his effort level, which partly determines $\pi$, after observing that contract.

Section II $A$ assumed that the loan generated a direct benefit of $B$ to the borrower; the loan did not affect the borrower's future income $Y$, but now the borrower's period 1 income is affected indirectly by his efforts to avoid insolvency. As a consequence, social welfare is the sum of the benefit from the loan, the borrower's future income, and his expected period 1 income, less the cost of avoiding insolvency: $W=B+Y+\pi y-\psi(\pi)$. The (social) first best would have the borrower set the marginal benefit of his efforts equal to their marginal costs. This yields

$$
y=\psi^{\prime}(\pi) \text {. }
$$

The borrower, however, has promised to repay his creditors out of his period 1 income if he is solvent, and so he chooses $\pi$ to maximize $W_{\mathrm{b}}=B$ $+Y+\pi(y-R)-\psi(\pi)$. The borrower's first-order condition (which also is sufficient in this case) thus sets

${ }^{16}$ See Ian Domowitz \& Robert L. Sartain, Determinants of the Consumer Bankruptcy Decision, 54 J. Fin. 403 (1999). 


$$
y-R=\psi^{\prime}(\pi) .
$$

Comparing the social first-order condition (1) to the borrower's private first-order condition (2), the left-hand side of condition (2) is less than the left-hand side of condition (1), so the borrower will work less hard to avoid insolvency than is socially optimal.

It may be illuminating to describe this result graphically. ${ }^{17}$ The hyperbola in Figure 1 represents the creditor's zero profit or participation constraint and is written as $R=D / \pi$. The concave downward-sloping curve represents the borrower's incentive compatibility constraint, written as $R=y-\psi^{\prime}(\pi)$. Both constraints can be satisfied only where the two curves cross; that is, where $y-\psi^{\prime}(\pi)=D / \pi$. The social surplus is the area under the concave curve. ${ }^{18}$ Hence, the first best would set $\pi$ where the concave curve crosses the axis, confirming the social first-order condition (1). The highest level of effort (of $\pi$ ) that satisfies both constraints, however, is the lower right crossing of the two curves, the point $\pi^{*}, R^{*}$. The near-triangular shaded area illustrates the deadweight loss. ${ }^{19}$

The inefficiency arises because the bankruptcy discharge makes the difference in payoffs in the two possible future states smaller for the borrower than it is for society. Put another way, the more "bankruptcy insurance" the borrower has, the less is the difference between the borrower's solvency and insolvency state returns, and the less hard he will work to avoid insolvency. Were there no bankruptcy discharge, the borrower would have to repay the debt regardless of his period 1 return, thereby making his private marginal incentive to exert effort equal to the social marginal incentive. $^{20}$

17 This and Figure 2 are similar to the figures in Sandeep Baliga \& Benjamin Polak, Banks versus Bonds: The Emergence and Persistence of Two Financial Systems (Discussion Paper No. 1221, Northwestern Univ., Managerial Econ. \& Decision Sci. Dep't 1998).

${ }^{18}$ Formally, this surplus is

$$
\int_{0}^{\pi^{*}}\left[y-\psi^{\prime}(\pi)\right] d \pi
$$

${ }^{19}$ We model a single credit extension. A common form of borrower moral hazard is to run up credit card debt shortly before bankruptcy. This has the effect in our model of raising the sum borrowed, $D$, thus tightening the creditors' participation constraint $D / \pi$ and thereby reducing the repayment probability $\pi$. See Figure 1 . The Code attempts to restrict some forms of "debt run up" by authorizing a bankruptcy court to dismiss a case for "substantial abuse."' See U.S.C. § 707(b).

${ }^{20}$ To see this formally, recall that without a bankruptcy discharge the buyer's expected wealth is $W_{\mathrm{bn}}=B+Y+\pi y-R-\psi(\pi)$. The borrower maximizes his expected wealth in this world by choosing $\pi$ such that $y=\psi^{\prime}(\pi)$. This is equation (1), the condition for social optimality. 


\section{B. Realizable Assets}

In this subsection, we retain the assumptions above but add that the borrower has assets to give up to creditors in the insolvency state. Two good effects follow from the debtor's possession of assets. First, the borrower is more motivated to avoid insolvency because he now has assets to protect. ${ }^{21}$ Second, the creditors will charge a lower interest rate (payable in the solvency state) because they receive a higher return in the insolvency state. Both effects induce the borrower to choose an effort level that is closer to the social optimum than the level the borrower would choose had he no assets to surrender.

To see how these effects increase ex ante efficiency, let a borrower have assets of $A$ that are below the value of his debt. Creditors earn $R$ in the solvency state, and, because the insolvency state return is zero, they earn $A$ when the borrower is bankrupt, where $A<R$. The zero-profit condition thus becomes $\pi R+(1-\pi) A=D$. Just as before, the social first best is given by the condition $y-\psi^{\prime}(\pi)=0$. The borrower, however, now chooses $\pi$ to maximize $W_{\mathrm{b}}=B+Y+\pi(y+A-R)-\psi(\pi)$. He thus will exert effort such that

$$
y+A-R=\psi^{\prime}(\pi) .
$$

The left-hand side of equation (3) is larger than the left-hand side of equation (2), which implies that the buyer will exert more effort to avoid insolvency.

We can illustrate the outcome with a graph similar to Figure 1. The hyperbola represents the creditor's zero-profit or participation constraint, written as $R-A=(D-A) / \pi$. The concave downward-sloping curve represents the borrower's incentive compatibility constraint, written as $R-A=$ $y-\psi^{\prime}(\pi)$. Once again, both constraints can be satisfied only where the two curves cross: that is, where $y-\psi^{\prime}(\pi)=(D-A) / \pi$. We consider four possible debtor asset levels, $A_{1}>A_{2}>A_{3}>A_{4}$. As the debtor's nonexempt assets increase, say, from $A_{2}$ to $A_{1}$, the hyperbola representing the zero-profit condition shifts down. The (relevant) intersection of the two curves thus shifts down and to the right: the difference in the amount the borrower promises to repay falls to $\left(R_{1}-A_{1}\right)<\left(R_{2}-A_{2}\right)$, and the probability of solvency increases to $\pi_{1}>\pi_{2}$. As the buyer has more assets to offer creditors when insolvent, efficiency is more closely approached and the deadweight loss area under the curve is reduced. Recall that when

${ }^{21}$ Domowitz \& Sartain, supra note 16, found that home ownership discourages bankruptcy but did not attempt to relate the possession of other assets to the insolvency probability. 


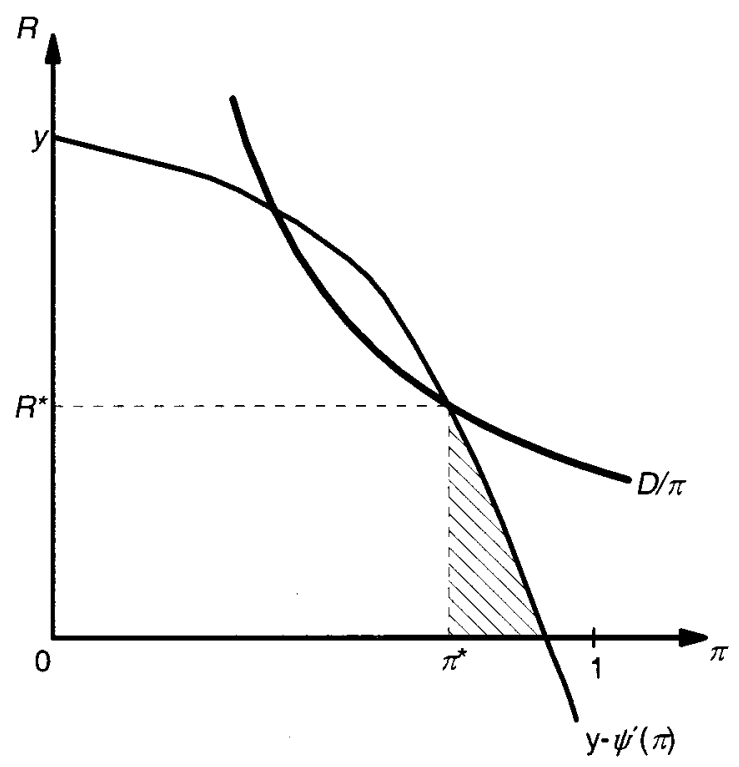

FIGURE 1.-The optimal debt contract without realizable assets

credit markets are competitive, the borrower captures the entire expected gain. $^{22}$

From a policy point of view, raising bankruptcy exemptions reduces the level of available assets and thus reduces efficiency. If exemptions become too high, some borrowers may be unable to obtain credit because there will be no contract that will satisfy both the lender's participation constraint and the borrower's incentive compatibility constraint. To illustrate this, observe that the asset level $A_{3}$ in Figure 2 (for which the constraint curves are just tangent) is the lowest asset level at which the borrower could obtain the loan $D$. The loan contract corresponding to asset level $A_{3}$ produces positive surplus: in addition to the direct benefit of the loan, $B$, the surplus generated by borrower efforts (the area under the concave curve) still exceeds the cost of the loan. The curve describing asset level $A_{4}$ characterizes a borrower with too few assets to sustain a loan of $D$. Since a loan at the tangency point

${ }^{22}$ Another way to phrase the result is to observe that the presence of assets essentially reduces the size of the loan over which the borrower exercises discretion. This reduces the magnitude of moral hazard. The creditors' participation constraint can be written as $R=A$ $+(D-A) / \pi$. As $A$ approaches $D$, the second term on the right-hand side approaches zero: the influence of $\pi$, and thus of borrower effort, on the terms of the lending agreement becomes negligible. 


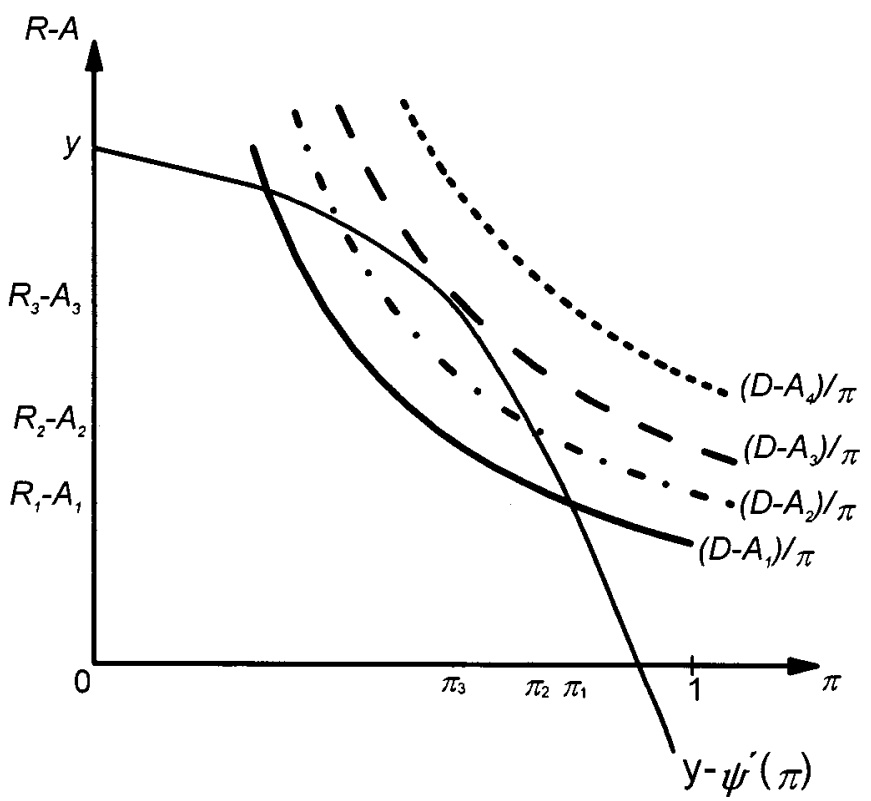

FIGURE 2.- Realizable assets and efficiency

still made strictly positive surplus, so also would some of the excluded loan contracts. ${ }^{23}$ The inefficiency cost of high exemption levels likely is hardest on relatively poor consumers. Many relatively poor persons have acquired some assets, but these borrowers are more likely than middle-class borrowers to have erratic income prospects. ${ }^{24}$

The results in Sections III $A$ and III $B$ can be summarized in the following:

Proposition 1:

a) If borrowers are risk neutral, a bankruptcy discharge is ex ante inefficient because it reduces to below the socially optimal level the borrower's effort to avoid bankruptcy.

${ }^{23}$ It has been shown (with a different model) that when there can be moral hazard, a firm that has few assets to offer to creditors in the insolvency state may be unable to borrow. See Alan Schwartz, The Absolute Priority Rule and the Firm's Investment Policy, 72 Wash. U. L. Q. 1213 (1994). This regrettable result can be produced by the law, when it reduces the assets that creditors can take after insolvency. There is some indirect evidence to support the result that the exemption level affects borrower incentives. Ronel Elul \& Narayanan Subramanian, Forum-Shopping and Personal Bankruptcy (Working Paper No. 99-1, Brown Univ., Dep't Econ. 1999), shows that borrowers sometimes move from low to high exemption states when bankruptcy is contemplated. If borrowers will do this, they likely also will exert effort initially to preserve assets.

${ }^{24}$ Under current exemption levels, 95 percent of Chapter 7 bankruptcies are no-asset cases. This suggests that raising these levels still further would injure both consumer borrowers and society. 
b) The inefficiency attributable to discharge is mitigated when the borrower has assets to give up to his creditors in the insolvency state.

c) Exemption laws remove assets from the bankrupt estate and thereby restore some of the ex ante inefficiency.

REMARK 1. Proposition $1 a^{25}$ implies that the bankruptcy discharge should be eliminated because the first best occurs when borrowers bear the entire insolvency risk. To eliminate discharge would not be optimal, however, because most borrowers are risk averse. Thus, a socially efficient consumer bankruptcy law would reflect a trade-off between risk and incentives. It is difficult to devise such a law, though, because risk aversion differs across individuals and is hard for the decision maker to observe. Thus, proposition 1 should be read only to tell decision makers not to neglect moral hazard considerations when choosing a bankruptcy system. Parts $b$ and $c$ of the proposition are in this spirit.

REMARK 2. Proposition $1 a$ also suggests that decision makers should seriously consider relaxing the current prohibition on contracting about bankruptcy. To the extent that the purpose of the bankruptcy discharge is to provide persons with partial wage insurance, a borrower should be permitted to choose how much insurance he wants to buy. A highly risk averse borrower would choose the full Chapter 7 discharge. A less risk averse borrower, or a borrower with considerable control over his future affairs, would buy less insurance-agreeing ex ante to repay a fraction of his debt if bankruptcy occurs. Such a contract would relax the creditor's participation constraint and thus increase the borrower's (and society's) expected surplus. Also, a borrower could condition a waiver of discharge on the nonoccurence of exogenous, verifiable events such as the failure of the borrower's employer or a sudden, serious illness. In a world of free contracting, discharge thus would be partial or conditional for many borrowers, the extent of these alterations depending on a borrower's preferences and circumstances.

We do not recommend free contracting in this article for technical and substantive reasons, however. Regarding the technical reasons, when a consumer borrower deals with several creditors, he may agree to inconsistent "bankruptcy terms.' For example, an unsophisticated consumer could agree to one set of bankruptcy procedures with creditor A and a different

${ }^{25}$ Hung-Jen Wang \& Michelle J. White, An Optimal Personal Bankruptcy Procedure and Proposed Reforms (unpublished manuscript, Univ. Michigan, Dep't Econ. 1999), obtains a result similar to proposition $1 a$ in a model in which moral hazard does not arise in connection with avoiding insolvency but rather from the penchant of insolvent debtors to engage in strategic behavior ex post: the debtors rearrange their assets to minimize the creditors' bankruptcy payoff. We consider the effect of this behavior below in our discussion of the debtor's choice of bankruptcy chapter. 
set with creditor B. Thus, some coordination mechanism may be necessary in consumer markets. ${ }^{26}$ Also, it may be very costly to specify all relevant contingencies in a contract. Finally, we assume that creditors know borrower failure probabilities (in equilibrium) and the distribution of risk aversion in the relevant population. If these assumptions are relaxed, efficient contracts would be more difficult to make.

Regarding the substantive reasons, the bankruptcy discharge is said to serve three goals. The first, as said, is to provide persons with partial wage insurance. The second is to internalize possible externalities associated with the extension of credit. A consumer who has a bad income realization and who lacks insurance may become a ward of the state. Also, a person whose income is liened will work less hard, and part of the cost may be externalized to an employer or the tax collector. Persons do not take these possible costs into account when borrowing money. ${ }^{27}$ The third goal of the bankruptcy discharge is to prevent "wage slavery": without a discharge, a debtor could be working partly for her creditors for a long time. Some observers may find the latter two goals sufficiently compelling to outweigh the virtues of freedom of contract. This article does not seriously analyze these technical and substantive concerns with consumer bankruptcy contracting. Rather, its goal is to exhibit the virtues that such contracting may yield and, thus, to move contracting issues from the periphery of consumer bankruptcy study to its center.

REMARK 3. Propositions $1 b$ and $1 c$ suggest that borrowers should be permitted to make partial or full exemption waivers. Unlike a waiver of the bankruptcy discharge itself, an exemption waiver is not substantively objectionable. An exemption waiver reduces the amount of insurance the borrower has but increases the amount of surplus the deal yields him. Subject to the technical concerns noted above, the borrower should be permitted to make this trade-off for himself. An exemption waiver also does not impair the borrower's postbankruptcy earning capacity, thereby implying that she will not become a ward of the state or a wage slave. ${ }^{28}$

An implicit assumption here is that the debtor's assets do not generate

${ }^{26}$ This difficulty would not apply to simple waivers of the right to discharge particular debts; these are analytically equivalent to giving security.

${ }^{27}$ The externality justification for discharge should not be overstated because the increase in interest rates that discharge causes may prevent a borrower from making investments that also generate positive externalities. For example, high interest rates may dampen demand for credit used to finance the borrower's education, and this may justify the current nondischargeability of government-subsidized student loans.

${ }^{28}$ A debtor today can effectively waive an exemption in certain property by giving a security interest in it. There may be a lack of coherence in a statute that prohibits discharge and exemption waivers but permits consumers to realize some of the effects of these waivers by giving security. 
income. Formally, the debtor's future income, $Y$, is unaffected by the value or character of the assets creditors can reach. This assumption sometimes is unrealistic. For example, consider a sole proprietor of a machine shop who files an individual bankruptcy petition under Chapter 7. If creditors can take all of her machines, her future earning power may be seriously impaired. The assumption of non-income-generating assets, however, covers a lot of cases: most consumer borrowers generate income only with their human capital. To the extent that this is false, our recommendations regarding exemptions should be modified.

\section{Renegotiation}

Many debtors reaffirm part or all of a debt after filing a Chapter 7 bankruptcy. A large number of these reaffirmations are with secured creditors and involve trading future income for the right to retain current nonexempt assets. Reaffirmations are heavily regulated today, and the NBRC in effect recommended that they be prohibited. Debtors are said often to make foolish reaffirmation bargains, in which they give up too much for what they get.

Reaffirmations (called here "renegotiations") have three effects. To understand these, realize that a typical asset has two values, its value to the debtor $\left(A^{\mathrm{D}}\right)$ and its value to the market $\left(A^{\mathrm{M}}\right)$. A creditor who repossesses, or who gets the value of the debtor's assets after discharge, realizes $A^{\mathrm{M}}$. We assume that $R>A^{\mathrm{D}} \geq A^{\mathrm{M}}$ (assets are worth less than the debt and generate surplus for their owners), so debtors always want to renegotiate. ${ }^{29}$ The first effect of reaffirmations is that they increase ex post surplus; that is, society realizes $A^{\mathrm{D}}$ rather than $A^{\mathrm{M}}$.

The other two consequences of reaffirmations affect ex ante efficiency and depend on the ex post bargaining power of the borrower and his creditors. ${ }^{30}$ Let $\beta \in[0,1]$ index the debtor's bargaining power, where $\beta=1$ means that the entire ex post surplus from renegotiation $\left(A^{\mathrm{D}}-A^{\mathrm{M}}\right)$ accrues to the debtor. In the usual case, bargaining power is shared. The debtor keeps his nonexempt assets and make a payment to the creditor (out of future income) of $A^{\mathrm{M}}+(1-\beta)\left(A^{\mathrm{D}}-A^{\mathrm{M}}\right)$. Competitive credit markets, anticipating this greater payment in the insolvency state, will force lenders to reduce the interest rate. ${ }^{31}$ When the interest rate falls, the borrower keeps

${ }^{29}$ If an exempt asset is worth more to the market than to the debtor, the debtor can sell the asset to his creditors. Such sales are not controversial because the debtor does not lien his future income.

${ }^{30}$ Our assumption that credit markets are competitive ex ante does not imply that creditors have no ex post bargaining power.

${ }^{31}$ This would here entail reducing the amount the borrower promises to repay: that is, lowering $R$. 
more of the marginal solvency state return and so will exert more effort to avoid bankruptcy. This second effect of reaffirmations is ex ante efficient. On the other hand, the debtor's share of the ex post surplus from renegotiation, $\beta\left(A^{\mathrm{D}}-A^{\mathrm{M}}\right)$, reduces the harshness of insolvency for the debtor (who previously lost the entire value of his nonexempt assets). This third effect reduces the incentive of a borrower to avoid bankruptcy and so is ex ante inefficient.

While it seems impossible to sign the effect of renegotiation in general, we can identify the parameters on which the sign depends.

Proposition 2. Renegotiation is ex ante efficient when $\pi \leq(1-\beta)$.

Proof. See Appendix A.

Regarding the intuition, a reaffirmation has two positive efficiency effects. First, it generates an ex post surplus in the insolvency state (this is $\left.A^{\mathrm{D}}-A^{\mathrm{M}}\right)$. Second, if the creditor expects to share in this surplus, interest rates in the solvency state will fall and the buyer's incentive to provide effort will increase. When the borrower will succeed with a relatively low probability ( $\pi$ is small), the second effect will be significant: if failure is a realistic prospect, the expected value of the insolvency state surplus is relatively large, and this will lower the interest rate and thereby increase the borrower's incentive to avoid bankruptcy. The third effect of reaffirmations is negative: renegotiation lowers the borrower's incentive to avoid bankruptcy because the borrower realizes part of the ex post surplus, but this effect is slight when the borrower has little ex post bargaining power ( $\beta$ is small). The creditor then keeps a large share of the surplus (which lowers the interest rate) and the borrower has a strong incentive to avoid bankruptcy because he does badly in it despite the opportunity to renegotiate. Proposition 2 thus holds that renegotiation is ex ante efficient when both $\pi$ and $\beta$ are small. The proposition, however, considers only how the success probability and the parties' ex post bargaining power can alter the ex ante efficiency effects that renegotiation produces. Consequently, the proposition is not an if and only if result: a renegotiation that failed to satisfy the proposition's inequality could be efficient all in all if it produced enough ex post surplus - the first effect. A renegotiation that does satisfy the inequality necessarily is efficient, though, because the surplus-generating effect of renegotiation always is positive and the latter two $\pi$ and $\beta$ effects would then be positive on net. ${ }^{32}$

REMARK 4. Proposition 2 suggests that renegotiation may help relatively poor borrowers, the group the NBRC was most concerned about. These borrowers may have less stable jobs or be less able to withstand

32 This analysis does not require renegotiation to be 100 percent ex post efficient. The proof of proposition 2 considers only renegotiations that recover ex post surplus at the margin. 
shocks to their wage income; hence, they are the group most likely to default. Also, relatively poor borrowers may have little bargaining experience and are less likely to be represented by lawyers. When $\pi$ and $\beta$ both are low, renegotiation maximizes expected social surplus, and the borrowers will capture all of this gain in the form of better ex ante credit. ${ }^{33}$

REMARK 5. Proposition 2 illustrates an additional way for bankruptcy contracting to increase efficiency. Consider three possible legal rules. (a) Reaffirmations are banned altogether. The ban could be efficient only when $\pi$ and $\beta$ are high, but perhaps not even then because the ban wipes out the insolvency state surplus. (b) Reaffirmations are permitted but ex ante bankruptcy contracts are banned. Permitting renegotiation restores the surplus but can yield inefficiency when $\pi$ and $\beta$ are high. (c) Both reaffirmations and partial bankruptcy waivers are permitted. Under this rule, a borrower for whom $\pi$ and $\beta$ are high could agree to pay to the creditor the borrower's share of the expected renegotiation surplus $\beta\left(A^{\mathrm{D}}-A^{\mathrm{M}}\right)$ out of her postbankruptcy income $Y$. The creditor thus would recover its share of the surplus $(1-\beta)\left(A^{\mathrm{D}}-A^{\mathrm{M}}\right)$ in the renegotiation plus this payment, ensuring to the creditor all of $A^{\mathrm{D}}-A^{\mathrm{M}}$ in the insolvency state. As a consequence, the waiver would increase the borrower's solvency state return above her return were waivers banned because competition would induce the creditor to reduce the interest rate below the nonwaiver rate. The borrower would benefit from the ex ante efficiency effect of this lower rate. Under the waiver, the insolvent borrower would retain surplus because she keeps the asset, but she must pay to the creditor the share of the ex post surplus that the creditor's bargaining power can command in the renegotiation and the remainder later, thus realizing an insolvency state return of $Y+B+\left(A^{\mathrm{D}}\right.$ $\left.-A^{\mathrm{M}}\right)-\beta\left(A^{\mathrm{D}}-A^{\mathrm{M}}\right)-(1-\beta)\left(A^{\mathrm{D}}-A^{\mathrm{M}}\right)=Y+B$. This is all the wage insurance that the bankruptcy system can provide. Therefore, this partial waiver permits the borrower to realize some of the efficiencies of bankruptcy contracting without sacrificing insurance coverage. Rule $c$, which combines reaffirmations and ex ante waivers, thus is preferable to rule $a$, which bans reaffirmations, or rule $b$, which bans waivers. ${ }^{34}$

These results rest importantly on the assumption that credit markets are competitive. When this assumption is relaxed, then the case the NBRC

33 Many borrowers reaffirm unsecured debts, apparently to increase their ability to get credit (a reaffirmation is a good signal of future willingness to repay). These reaffirmations have good ex ante incentive effects. Creditors who anticipate getting reaffirmations will reduce the interest rate, yet because bankruptcy would remain hard on the borrower, he will not exert less effort to avoid it.

${ }^{34}$ Remarks 2 and 3 regarding the technical difficulties with consumer bankruptcy contracting and the substantive permissibility of waivers also apply here and to remark 6 infra. 
imagined exists: renegotiation disadvantages borrowers with little bargaining power (a low $\beta$ ). Formally, we have the following:

PROPOSITION 3. If the creditor has a monopoly at the lending stage but the borrower retains some of the (ex ante) surplus that the equilibrium lending agreement creates, then renegotiation is advantageous to the borrower when $\beta>1 / 2$. As $\beta$ approaches zero, renegotiation harms the borrower.

Proof. See Appendix B.

We first set out the intuition and then argue that the result should not influence bankruptcy policy. To begin, retain all of the assumptions made above except let the creditor have a monopoly at the lending stage and then assume that reaffirmations are banned. The creditor could raise $R$ (and thus the interest rate) to the monopoly level, but the success probability $\pi$ falls when $R$ increases. The creditor in this legal world earns $R$ when the borrower succeeds and $A^{\mathrm{M}}$, the market value of the borrower's nonexempt assets, when the borrower fails. Thus, the cost to the creditor of raising $R$ is the marginal decrease in $\pi$ times the creditor's marginal gain from success $\left(R-A^{\mathrm{M}}\right)$. Because this cost is positive, the creditor has a strong incentive not to raise $R$ to the monopoly level, thereby leaving the borrower with some ex ante surplus. Put concisely, moral hazard will here constrain monopoly pricing. ${ }^{35}$

Now assume that renegotiation is permissible and consider the extreme case where the borrower has no bargaining power $(\beta=0)$. Unlike a similar borrower when the credit market is competitive, this borrower is made worse off by renegotiation. Neither borrower will realize ex post surplus, but in the monopoly case the interest rate rises when the borrower lacks ex post bargaining power, while in the competitive case the interest rate declines. To understand why the rate increases in the monopoly case, recall that when the borrower has no ex post bargaining power and renegotiation is permitted, the creditor captures all of the ex post surplus and so its insolvency state payoff rises to $A^{\mathrm{D}}$. As a consequence, the marginal cost of increasing $R$ becomes the marginal decrease in $\pi$ times $\left(R-A^{\mathrm{D}}\right)$. This is a smaller cost than when renegotiation is banned, because $A^{\mathrm{D}}>A^{\mathrm{M}}$, so the creditor will raise $R$. Therefore, when the creditor has market power ex ante and bargaining power ex post, the borrower, who likely is a relatively poor person, not only realizes little ex post surplus but also faces a higher interest rate. ${ }^{36}$

\footnotetext{
${ }^{35}$ When the creditor has market power, two cases can arise. In the more common one just described, the borrower's participation constraint is slack; the buyer retains ex ante surplus. It can happen, though, that this constraint will bind.

${ }^{36}$ Similar analysis of a monopoly lender's market reveals that a borrower with nonexempt assets faces a higher interest rate than an otherwise identical borrower with no such asset. Any nonexempt asset, like the lender's share of surplus from an asset subject to reaffirmation,
} 
Now consider the second extreme case, in which the borrower has all of the ex post bargaining power $(\beta=1)$. The interest rate will fall for this borrower relative to the borrower with little bargaining power, for two reasons. First, the marginal cost to the creditor of raising the interest rate is restored to the marginal decrease in $\pi$ times $\left(R-A^{\mathrm{M}}\right)$ because the creditor now realizes no ex post surplus. Regarding the second reason, the borrower now has a smaller incentive to avoid bankruptcy because bankruptcy is less harsh on him and so $\pi$ falls. When the probability that the creditor will be repaid declines, the marginal benefit of increasing the interest rate $R$ also declines. Therefore, a borrower with considerable ex post bargaining power both keeps more of the ex post surplus and pays a lower interest rate. Proposition 3 characterizes these results precisely, stating that a sufficient condition for renegotiation to become beneficial to the borrower is that he have more than half the ex post bargaining power.

Proposition 3 should not count in favor of banning or restricting reaffirmations, however. As a matter of fact, credit markets appear competitive, so the proposition likely describes few real-world cases. Furthermore, monopoly power in credit markets often is a consequence of regulation. Hence, often a good response to it is to reduce barriers to entry. Apart from this, it is better to attack market power directly with the antitrust laws than attempt to ameliorate one of its many effects by regulating reaffirmations.

\section{Renegotiation and the Debtor's Choice of Bankruptcy Chapter}

That debtors can renegotiate in Chapter 7 also implies that there is an efficiency cost to permitting an insolvent debtor to choose which bankruptcy chapter to use. Renegotiation in Chapter 7 permits the parties to realize $A^{\mathrm{D}}-A^{\mathrm{M}}$, the difference between the value of an asset to the debtor and to the market. Chapter 13 may redistribute this surplus-by permitting the borrower to pay the creditor less than in a Chapter 7 renegotiation-but cannot increase it. It remains to show that the availability of Chapter 13 worsens ex ante efficiency. Begin with the debtor's choice between chapters. A Chapter 13 debtor can keep all of his assets but must pay over all of his disposable income to his creditors. The debtor will ignore exempt assets when choosing between these chapters because both permit him to keep them.

Turning to nonexempt assets, let the bankruptcy court permit a Chapter

increases the lender's insolvency state payoff and thus implies a higher $R$. This observation, however, is of little consequence for bankruptcy policy, as there is of course no proposal that borrowers generally be deprived of their nonexempt assets! 
13 debtor to keep $\Phi$ of his postbankruptcy income $Y$, where $0<\Phi<1$. $^{37}$ The price of keeping an exempt asset in Chapter 13 thus is $(1-\Phi) Y$, the sum in present value terms that creditors get. The debtor will compare the prices for keeping the asset that the two chapters set. Chapter 13 is preferable when $(1-\Phi) Y<\left[A^{\mathrm{M}}+(1-\beta)\left(A^{\mathrm{D}}-A^{\mathrm{M}}\right)\right]$. The term in brackets on the right-hand side is the Chapter 7 renegotiation payment the debtor makes to the creditor in order to keep the asset. This expression simplifies to (1 $\Phi) Y<A^{\mathrm{D}}+\beta\left(A^{\mathrm{D}}-A^{\mathrm{M}}\right)$. Hence, debtors prefer Chapter 13 when they can keep a large share of their postbankruptcy income ( $\Phi$ is big), when they have a high valuation for the asset ( $A^{\mathrm{D}}$ is big), when they have little bargaining power in Chapter 7 ( $\beta$ is small), and when there is little surplus over which to renegotiate $\left(A^{\mathrm{D}}-A^{\mathrm{M}}\right.$ is small). ${ }^{38}$

More significant, the parties' preferences conflict. To see how, let $A^{\mathrm{D}}$ $-A^{\mathrm{M}}=x$ so the debtor prefers to use Chapter 13 when $(a)(1-\Phi) Y<$ $A^{\mathrm{D}}-\beta x$. The creditors prefer the debtor to use Chapter 13 when the Chapter 13 payment to them is larger than the share of the renegotiation surplus they can extract in Chapter 7, that is, when $(b)(1-\Phi) Y>A^{\mathrm{D}}-\beta x$. Intuitively, the debtor will choose the chapter that minimizes the price for keeping the asset, while the creditors would prefer him to choose the chapter that maximizes the price. Hence, when the debtor files for bankruptcy under Chapter 7, his creditors would have preferred him to file under Chapter 13.

Turning to ex ante efficiency, because debtors use Chapter 13 when they do better under it than they would do in a Chapter 7 renegotiation, the availability of Chapter 13 makes bankruptcy less harsh on borrowers in expectation and they will work less hard to avoid it. Also, because Chapter 13 permits debtors to minimize the creditors' ex post payment, its existence causes creditors to raise the interest rate. This further worsens the borrower's incentives because the borrower can keep less of the marginal solvency state return and so will exert less effort to maximize that return.

Another way to explain this result is to refer to proposition 2, which

37 The bankruptcy court should set $\Phi$ to eliminate the borrower's disposable income. Thus, $\Phi$ is a function of the borrower's post-bankruptcy income $Y$. We assume that bankruptcy has no effect on $Y$, and this implies that $\Phi$ is exogenous. A debtor can redeem a nonexempt asset in Chapter 7 by paying the debt in a lump sum, while he can keep the asset and make installment payments in Chapter 13. This difference in the mode of payment is said to bias debtors to choose Chapter 13, but a Chapter 7 reaffirmation can involve paying the debt plus a fraction of the ex post surplus in installments. Thus, we do not consider payment modes when discussing the debtor's choice between the two chapters.

${ }^{38}$ Domowitz \& Sartain, supra note 7, and Domowitz \& Sartain, supra note 16, find that borrowers are more likely to choose Chapter 7 when the exemption level is high. This is consistent with the analysis here: a high exemption level implies that a borrower is less likely to have nonexempt assets that are worth a lot to him (that is, $A^{\mathrm{D}}$ is small). 
showed that renegotiation increases ex ante efficiency when $\pi<1-\beta$. The availability of Chapter 13 increases the debtor's bargaining power (increases $\beta$ ) because creditors may have to bribe the borrower to use Chapter 7. When the debtor has more bargaining power ex post, the inequality is harder to satisfy and renegotiation is less likely to be ex ante efficient. This analysis can be summarized in the following.

Proposition 4. There is an efficiency cost to permitting borrowers to choose between Chapters 7 and 13 because Chapter 13 cannot increase ex post efficiency and giving debtors the option worsens ex ante efficiency.

REMARK 6. A highly risk averse borrower might prefer ex ante to retain the choice of filing under Chapter 7 or Chapter 13 because this maximizes the borrower's insolvency state payoff and thus gives him more insurance. Proposition 4 thus does not support repeal of Chapter 13, but it does suggest that borrowers should be allowed to waive their right to use either Chapter 7 or Chapter 13 (making the nonwaived section operative). A borrower would offer a waiver when the improvement in his ex ante terms of trade would exceed the expected value of any increased ex post benefit from having a choice of chapters. Such contracts would increase efficiency but are unenforceable today.

REMARK 7. Requiring high-income debtors to use Chapter 13, as with needs-based bankruptcy, could improve ex ante efficiency in two ways. First, if borrowers are risk neutral, then proposition $1 a$ showed that they would reject bankruptcy insurance. Chapter 13 requires debtors to pay over all of their disposable income to creditors and thus leaves borrowers largely uninsured. Second, debtors have less bargaining power in Chapter 13 than in Chapter 7 because the Chapter 13 creditor has a more powerful threat point if the parties cannot agree. Proposition 2 showed that ex ante efficiency increases (in the competitive case) when the debtor's bargaining power declines. Many borrowers, however, are risk averse. As to these borrowers, the law must harmonize the conflicting goals of insuring borrowers and providing them with appropriate incentives. A mandatory Chapter 13 would not be optimal in this world because bankruptcy would then provide less insurance than almost any borrower would want. Therefore, the alternatives of permitting free contracting or reducing a borrower's bargaining power in Chapter 7 should be considered and rejected before advocating a mandatory Chapter 13.

\section{E. Renegotiation and the Debtor's Human Capital}

The fresh-start policy embodied in Chapter 7 permits a debtor to emerge from bankruptcy with his human capital intact. Remark 2 above noted that for some the discharge is substantively desirable because liens on a per- 
son's income may cause externalities or be thought a form of wage slavery. A very strong commitment to the fresh-start policy thus would also imply prohibiting reaffirmations, which lien the borrower's future income. That strong a commitment to the policy is hard to justify, however.

A debtor who renegotiates in Chapter 7 is restoring part or all of a debt. If society permits person to incur debts, it apparently also should permit reaffirmations. Also, society today permits a debtor to lien a large portion of his future income in Chapter 13. If a lien is permissible under one bankruptcy chapter, it is difficult to see why the same or a smaller lien should be impermissible under the other.

To be sure, the debtor has failed once and so may be thought to be less trustworthy. This seems a weak ground on which to ban reaffirmations. ${ }^{39}$ Bankruptcy seldom is a happy experience, so a debtor is likely to be more careful when bargaining while insolvent than he was when incurring the original debt. Also, creditors who agree to reaffirmations are trading the right to receive an asset today for a claim on the debtor's future income. The creditors' desire to be repaid suggests that market discipline will help to prevent reaffirmation bargains that debtors are unlikely to keep. These arguments suggest that while a desire to protect a person's human capital implies that there should be a bankruptcy discharge, that desire does not also imply the prohibition of efficient partial waivers.

\section{CONCLUSION}

This paper attempts to contribute to the small literature that treats consumer bankruptcy theoretically. It argues that a consumer bankruptcy system should have two ex ante goals: to insure consumers, to the extent possible, against bad income realizations and to reduce moral hazard in connection with lending agreements. These two objectives are in tension because the borrower's incentive to avoid bankruptcy is decreasing in the extent to which bankruptcy insures him. As an example, permitting the borrower to offer his creditors assets as well as income in the insolvency state will increase ex ante efficiency. When creditors can reach assets, their insolvency state payoffs increase, thereby inducing a fall in the interest rate. This improves the borrower's incentive to stay solvent; he can keep more of the marginal solvency state return. Also, when the borrower has assets to pro-

39 Some reformers who oppose reaffirmations on the ground that sophisticated creditors will exploit unsophisticated borrowers who mistakenly took on too much debt also claim that insolvency is exogenous. These positions are in tension because an inference that a person is commercially incompetent cannot rest on a bankruptcy caused by an exogenous event. Hence, if consumers can be trusted to borrow initially, they apparently should be trusted to reaffirm. 
tect, he will work harder to avoid bankruptcy. Consequently, raising the personal exemption level would reduce ex ante efficiency. On the other hand, lowering the exemption level reduces the amount of wage insurance that the bankruptcy system provides.

The tension between risk and incentives is partly mitigated by renegotiation; reaffirmations permit borrowers to increase the creditors' payoff in the insolvency state, and this can improve the borrower's incentive to exert effort to stay solvent. The desirable effects of reaffirmations are more likely to benefit relatively less well-off consumers. This suggests that current restrictions on reaffirmations should be relaxed and proposals to limit reaffirmations still further are unwise.

An ex post efficient bankruptcy system would permit debtors to trade claims on their future income for the right to retain nonexempt assets and, also, will not excessively lien a debtor's human capital. Debtors can make the requisite trades in Chapter 7 renegotiations. Hence, Chapter 13 cannot increase ex post surplus, and, we show, offering debtors the option to choose a bankruptcy chapter worsens ex ante efficiency because it makes bankruptcy too soft on debtors and lowers the creditors' expected insolvency state payoff. On the other hand, the ability to choose between chapters increases the borrower's ex post payoff and thus provides a little more insurance for very risk averse debtors. Reform proposals to make Chapter 13 mandatory seem ill advised because that would eliminate much of bankruptcy's insurance function. Rather, we argue that consideration be given to permitting consumer borrowers to waive their right to choose between chapters in the lending agreement. Many consumers likely would prefer the better terms of trade that waiver would yield to the extra insurance that a choice of chapter provides.

Perhaps of greatest importance, serious consideration should be given to permitting consumers to contract about bankruptcy. In a world where the cause of bankruptcy is exogenous (there is no moral hazard), consumers would reject contracts that reduced current bankruptcy protections because consumers prefer full insurance. In the world in which we live, a borrower commonly has some control over his fate. Society permits persons to trade off risk and incentives in most of the commercial contexts in which they function. Relevant here, creditors could offer borrowers lending agreements that will induce constrained efficient trade-offs between insurance and incentives, and the borrowing side will get the benefit of this efficiency. We have not carefully analyzed the technical and substantive concerns that consumer bankruptcy contracting raise, however, so our proposals to increase free contracting should be regarded more as an agenda for research than as the advocacy of legal change.

This paper evaluates bankruptcy law with the efficiency norm because 
reforms that increase ex ante efficiency also benefit consumer borrowers, who realize the entire ex ante social surplus from lending agreements in competitive credit markets. Reaffirmations also help consumer borrowers by letting them keep a share of the surplus that asset ownership generates. Nevertheless, a harsh bankruptcy law is harsh, and we now have only two things to say about this. First, even under the reforms we tentatively advocate, borrowers would emerge from bankruptcy with their human capital intact, except where they lien portions of it to keep assets that are particularly valuable to them. Thus, we would preserve much of bankruptcy's insurance function. Second, while efficiency should be tempered with compassion, the issue is how to realize this trade-off in the form of administrable bankruptcy rules. No one, including us, has made much progress with this question. ${ }^{40}$

Reformers such as the NBRC claim that a good consumer bankruptcy system would ensure equality of result among creditors, reduce strategic behavior by debtors, and increase uniformity in administering the law. The pursuit of equality among creditors makes little sense in the bankruptcy context for two reasons. (a) In the zero-profit equilibria that commonly obtain in credit markets, no creditor does very much better than the others. ${ }^{41}$ (b) Pursuing equality among creditors disadvantages debtors, especially the least well off of them, by severely restricting reaffirmations and also by reducing the creditors' incentive to develop more efficient collection mechanisms. The other two reformer goals would be largely achieved by the legal changes suggested here. As an example, two of the most common forms of strategic behavior are converting nonexempt assets into exempt assets on the eve of bankruptcy and using Chapter 13 strategically to stay foreclosure when the debtor has no serious hope of complying with a repayment plan. Debtors would gain less from rearranging their assets were the exemption level reduced and were they more able to give security in their property. The second form of strategic behavior would be ameliorated were borrowers permitted to waive their right to use Chapter 13. Similarly, much of the nonuniformity in current administration is in Chapter 13, and this too would diminish if the chapter were used less frequently.

${ }^{40}$ In the business context, there is an efficiency trade-off between soft and hard bankruptcy procedures. A hard procedure has desirable ex ante incentive effects, but insolvent firms are reluctant to use it. When creditors can observe insolvency only with a lag, the firm thus may keep payments current while it dissipates assets. This is ex post inefficient. See Paul Povel, Optimal "Soft", or “'Tough" Bankruptcy Procedures, 15 J. L. Econ. \& Org. 659 (1999). We do not model this trade-off here. Many insolvent consumers lack the cash to stall creditors for very long while they dissipate assets, and, as shown, they often prefer to keep their assets intact.

${ }^{41}$ See note 14 supra. 
Regrettably, the reforms urged here will have a hard time in Congress. Current business and consumer bankruptcy law ban free contracting over bankruptcy and force insolvents into the system. The system also creates incentives for parties to use its most costly parts-Chapter 11 for business bankruptcy and Chapter 13 for consumer bankruptcy. Reform proposals, such as needs-based bankruptcy, would increase the use of Chapter 13. In addition, current law requires many fact-specific inquiries. For example, courts are supposed to find whether a reaffirmation is in a debtor's best interests. The current business and consumer bankruptcy systems thus substantially benefit the bankruptcy bar, the bankruptcy judges, and the academics whose consulting income increases with the cost, complexity, and court centeredness of the system. These groups have dominated the current reform debate and past debates as well. Informal speculation plausibly suggests that we have the consumer bankruptcy system that the lawyers want. $^{42}$

\section{APPENDIX A}

Appendix A proves proposition 2. To begin, let $\alpha \in(0,1)$ index the effectiveness of renegotiation, where $\alpha=0$ implies no renegotiation and $\alpha=1$ implies renegotiation. Also, let $A^{\mathrm{D}}-A^{\mathrm{M}}=x$, the renegotiation surplus. The social surplus from a lending agreement is $\mathrm{SS}=B+\pi\left(y+A^{\mathrm{D}}\right)+(1-\pi)\left(A^{\mathrm{M}}+\alpha x\right)-\psi(\pi)$. The marginal social surplus then is MSS $=d(\mathrm{SS}) / d \pi=y+(1-\alpha) x-\psi^{\prime}(\pi)$. The creditors' participation constraint - the zero-profit condition-is $D=\pi R+(1-\pi)\left[A^{\mathrm{M}}\right.$ $+\alpha(1-\beta)(x)]$. It will later be convenient to have this condition rewritten as

$$
R-\left[A^{\mathrm{M}}+\alpha(1-\beta)(x)\right]=\frac{D-\left[A^{\mathrm{M}}+\alpha(1-\beta)(x)\right]}{\pi} .
$$

Given the lending agreement, the borrower chooses $\pi$ to maximize $\pi\left(y+A^{\mathrm{D}}-R\right)$ $+(1-\pi) \alpha \beta(x)-\psi(\pi)$. The first-order condition for a private optimum thus is $y$ $+A^{\mathrm{D}}-\alpha \beta(x)-\psi^{\prime}(\pi)=R$. This can be rewritten as

$$
y+(1-\alpha)(x)-\psi^{\prime}(\pi)=R-A^{\mathrm{M}}-\alpha(1-\beta)(x) .
$$

The left-hand side of equation (A2) is the marginal social surplus, and the righthand side is the left-hand side of the zero-profit condition in equation (A1). Combining equations (A1) and (A2) yields an implicit definition of $\pi(\alpha)$, which tells how renegotiation affects the failure probability:

$$
y+(1-\alpha)(x)-\psi^{\prime}(\pi)=\frac{D-\left[A^{\mathrm{M}}+\alpha(1-\beta)(x)\right]}{\pi} .
$$

${ }^{42}$ For similar views, see Eric A. Posner, The Political Economy of the Bankruptcy Reform Act of 1978, 96 Mich. L. Rev. 47 (1997); David A. Skeel, Jr., Bankruptcy Lawyers and the Shape of American Bankruptcy Law, 67 Fordham L. Rev. 497 (1998), which concludes (at 521), "[B]ankruptcy lawyers exert significant influence over the shape of the bankruptcy process, and they have a strong incentive to maximize the use of bankruptcy.', 
In addition,

$$
-\psi^{\prime \prime}(\pi)<-\frac{D-\left[A^{\mathrm{M}}+\alpha(1-\beta)(x)\right]}{\pi^{2}}
$$

(otherwise, we are at a minimum), which implies

$$
\pi \psi^{\prime \prime}(\pi)>\frac{D-\left[A^{\mathrm{M}}+\alpha(1-\beta)(x)\right]}{\pi} .
$$

From equation (A3), the right-hand side of equation (A4) is the marginal social surplus (MSS).

Renegotiation has two relevant effects: it creates ex post surplus and it alters a borrower's incentives. The effect of renegotiation on social surplus thus can be written as

$$
\frac{d(\mathrm{SS})}{d \alpha}=(1-\pi)(x)+\frac{d \pi}{d \alpha} \frac{d(\mathrm{SS})}{d \pi} .
$$

The first term in this equation captures the direct effect of increasing ex post surplus, and the second term captures the indirect effect. The first term is positive because $x=A^{\mathrm{D}}-A^{\mathrm{M}}$. Also, $d(\mathrm{SS}) / d \pi$ is positive because the social surplus is increasing in the success probability of the borrower. Hence, renegotiation will increase social surplus when $d \pi / d \alpha$ is positive. To see when this can happen, totally differentiate equation (A3) with respect to $\alpha$. Doing this and rearranging terms yields

$$
\frac{d \pi}{d \alpha}\left[\operatorname{MSS}-\pi \psi^{\prime \prime}(\pi)\right]=-(x)[(1-\beta)-\pi] .
$$

The term inside the braces on the left-hand side of this expression is negative by equation (A4). Because $x$ is positive, the right-hand side of the expression will be negative; hence, $d \pi / d \alpha$ is positive when $\pi<(1-\beta)$. In this event, renegotiation increases social surplus and thus is ex ante efficient. This proves the proposition.

\section{APPENDIX B}

Appendix B proves proposition 3. The creditor chooses the interest rate $R$ taking into account the effect that $R$ will have on the borrower's choice of effort and hence on the success probability $\pi$ (the text shows that an implication of this choice often is to leave the borrower with some ex ante surplus, and we analyze this case here). Begin with the borrower's problem. Given $R$, the borrower chooses $\pi$ to maximize

$$
B+Y+\pi\left(y+A^{\mathrm{D}}-R\right)+(1-\pi)\left[\alpha \beta\left(A^{\mathrm{D}}-A^{\mathrm{M}}\right)\right]-\psi(\pi) .
$$

As just said, the lender will choose $R$ such that $\pi>0$, and by our assumption that $\psi^{\prime}(1)=\infty$, we know that $\pi<1$. Hence, we can assume an interior equilibrium, with the borrower choosing $\pi$ to solve the first-order condition

$$
\left(y+A^{\mathrm{D}}-R\right)-\left[\alpha \beta\left(A^{\mathrm{D}}-A^{\mathrm{M}}\right)\right]-\psi^{\prime}(\pi)=0 .
$$

Since we have assumed that $\psi^{\prime \prime}(\pi)<0$, the borrower's second-order condition is satisfied.

Let $\pi *(R ; \alpha)$ solve equation (B1). Hence, $\pi *(R ; \alpha)$ is the effort level that a borrower chooses who faces interest rate $R$ and who anticipates renegotiation at level 
$\alpha$. For convenience, write this effort level as $\pi^{*}$ and let the derivative of this with respect to $R$ be $\pi_{R}^{*} R$ (and so forth). We then get
(a) $\pi_{R}^{*}=\frac{-1}{\psi^{\prime \prime}\left(\pi^{*}\right)}$,
(b) $\pi_{\alpha}^{*}=\frac{-\beta\left(A^{\mathrm{D}}-A^{\mathrm{M}}\right)}{\psi^{\prime \prime}\left(\pi^{*}\right)}$,
(c) $\pi_{R R}^{*}=-\frac{\psi^{\prime \prime \prime}\left(\pi^{*}\right)}{\left[\psi^{\prime \prime}\left(\pi^{*}\right)\right]^{3}}$,
(d) $\pi_{R \alpha}^{*}=\frac{-\beta\left(A^{\mathrm{D}}-A^{\mathrm{M}}\right) \psi^{\prime \prime \prime}\left(\pi^{*}\right)}{\left[\psi^{\prime \prime}\left(\pi^{*}\right)\right]^{3}}$.

Our assumptions on $\psi$ imply that all of these derivatives are negative. To get a sense of what these mean, $a$ holds that raising $R$ causes $\pi$ to fall and $b$ holds that raising $\alpha$ also causes $\pi$ to fall (because renegotiation is more effective and so the borrower gets more of the ex post surplus and so works less hard).

We turn now to the creditor's problem, which is to choose $R$ (anticipating its effect on $\pi$ ) to maximize

$$
\pi * R+\left(1-\pi^{*}\right)\left[A^{\mathrm{M}}+\alpha(1-\beta)\left(A^{\mathrm{D}}-A^{\mathrm{M}}\right)\right] .
$$

Differentiating equation (B2) with respect to $R$ gives the first-order condition

$$
\pi^{*}+\pi_{R}^{*} Z=0 \text {. }
$$

The first term is the marginal gain of raising the interest rate, and the second term is the marginal cost. Regarding this term, $Z$ is the marginal benefit to the creditor of the borrower's success. Formally, $Z \equiv R-\left[A^{\mathrm{M}}+\alpha(1-\beta)\left(A^{\mathrm{D}}-A^{\mathrm{M}}\right)\right]$, and $Z$ $>0$.

Let $R^{*}(\alpha)$ be the interest rate that solves equation (B3). The issue is how this equilibrium interest rate varies with $\alpha$. Totally differentiating equation (B3) with respect to $\alpha$ and collecting terms yields

$$
\begin{aligned}
R_{\alpha}^{*}\left(\pi_{R R}^{*} Z+2 \pi_{R}^{*}\right) & =\pi_{R}^{*}(1-\beta)\left(A^{\mathrm{D}}-A^{\mathrm{M}}\right)-\pi_{\alpha}^{*}-\pi_{R \alpha}^{*} Z \\
& =\frac{[\beta-(1-\beta)]\left(A^{\mathrm{D}}-A^{\mathrm{M}}\right)}{\psi^{\prime \prime}\left(\pi^{*}\right)}+\frac{\beta\left(A^{\mathrm{D}}-A^{\mathrm{M}}\right) \psi^{\prime \prime \prime}\left(\pi^{*}\right) Z}{\left[\psi^{\prime \prime}\left(\pi^{*}\right)\right]^{3}} .
\end{aligned}
$$

From the derivatives above, we know that $\left(\pi_{R R}^{*} Z+2 \pi_{R}^{*}\right)<0$. Therefore, if $\beta>$ $(1-\beta)$, the right-hand side is positive and $R_{\alpha}^{*}<0$. On the other hand, if $\beta=0$, the right-hand side is negative and $R_{\alpha}^{*}>0$.

Consider the case when $\beta>(1-\beta)$. As $\alpha$ increases, the borrower faces a lower interest rate in the solvency state and retains a larger share of the surplus in the insolvency state. Thus, the borrower is better off even if he holds his choice of $\pi$ fixed at what now is not the optimum level. Assume next that $\beta=0$ so that $R_{\alpha}^{*}>$ 0 . In this case, as $\alpha$ increases, the borrower must pay a higher interest rate in the solvency state and retains no ex post surplus in the insolvency state. Thus, he is strictly worse off. By continuity, this result holds for $\beta$ sufficiently small. This proves the proposition. 

All use subject to JSTOR Terms and Conditions 